\title{
Low Pulmonary Arterial Wedge Pressure
}

National Cancer Institute

\section{Source}

National Cancer Institute. Low Pulmonary Arterial Wedge Pressure. NCI Thesaurus. Code C50642.

The measurement of the mean left pulmonary arterial pressure, as measured by a catheter introduced into the distal pulmonary artery, is low. 